\title{
Translation, cultural adaptation and validation of "Pregnancy Experience Scale" for Brazilian pregnant
}

\author{
Tradução, adaptação cultural e validação da "Pregnancy \\ Experience Scale" para gestantes brasileiras
}

Traducción, adaptación y validación de la "Pregnancy Experience Scale" para brasileñas embarazadas

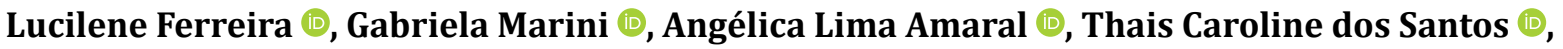 \\ Marta Helena Souza de Conti $(\mathbb{*} *$
}

Universidade do Sagrado Coração (USC), Bauru, SP, Brazil

\begin{abstract}
Introduction: The analysis of maternal psychosocial stress during pregnancy can be an important intervention tool for maternal and infant health. Objective: To translate, culturally adapt and validate the Pregnancy Experience Scale - Brief Version - into Brazilian Portuguese for Brazilian pregnant women. Method: The scale was carried out according to the guidelines recommended by Beaton and his collaborators. Data were collected between January and September of 2016, in hospitals, basic health units, and community. In total, 206 pregnant women with an average age of $25.01 \pm 6.44$ years and gestational age of $25.5 \pm 8.72$ pregnancy weeks answered the scale for the process of psychometric analysis and validation. Results: The results indicated a two-dimensional model of the scale with two factors: Positive Experiences and Negative Experiences. The reliability was established through Cronbach's Alpha Test $(\alpha>0.70)$. The
\end{abstract}

* LF: PhD, e-mail: luci_ferreira2003@yahoo.com.br GM: PhD, e-mail: gacamarini@yahoo.com.br ALM: BS, e-mail: angelica.lusc@gmail.com TCS: BS, e-mail: thais.caroline@hotmail.com MHSC: PhD, e-mail: madeconti@yahoo.com.br 
value found for the positive experiences factor was appropriate, $\alpha=0.77$. The same happened to the Negative Experiences factor, $\alpha=0.80$. These values provide evidence of the scale reliability. The convergent and concurrent validity of the instrument was established. Conclusion: The result of the psychometric study of the scale pointed out that the Pregnancy Experience Scale is an important intervention tool for the health care of mother and newborn, besides being a useful instrument to assess the experience of the women with the pregnancy, especially, the level of psychosocial stress, contributing to broaden the research in this area and subsidize support strategies for this population and women's health policies.

Keywords: Pregnancy. Surveys and Questionnaires. Psychometrics. Validation Studies.

\section{Resumo}

Introdução: A análise do estresse psicossocial materno durante a gravidez pode ser uma ferramenta de intervenção importante para a saúde da mãe e do recém-nascido. Objetivo: Traduzir, adaptar culturalmente e validar para a Língua Portuguesa no Brasil a Pregnancy Experience Scale - Short-Form, em gestantes brasileiras. Método: Foi realizada a tradução e Adaptação Cultural da escala para a Língua Portuguesa seguindo as recomendações do Guia proposto por Beaton e colaboradores. Os dados foram coletados entre janeiro e setembro de 2016, em hospitais, unidades básicas de saúde e comunidade. No total, 206 gestantes com média de idade de $25,01 \pm 6,44$ anos e idade gestacional de 25,5 \pm 8,72 semanas de gestação responderam a escala para o processo de análise psicométrica e validação. Resultados: Os resultados indicaram um modelo bidimensional da escala com dois fatores: Experiências Positivas e Experiências Negativas. A confiabilidade foi estabelecida por meio do teste de Alpha da Cronbach $(\alpha>0,70)$. Para o fator Experiências Positivas o valor encontrado foi adequado, sendo $\alpha=0,77$. O mesmo ocorreu com o fator "Experiências negativas", $\alpha=0,80$. Estes valores fornecem evidências da confiabilidade da escala. Foi estabelecida a validade convergente e concorrente do instrumento. Conclusão: o resultado do estudo psicométrico da escala apontou que a Pregnancy Experience Scale é uma ferramenta de intervenção importante para a assistência à saúde da mãe e do recém-nascido, além de ser um instrumento útil, para avaliar a experiência da mulher com a gravidez, especialmente, o nível de estresse psicossocial, contribuindo para ampliar as pesquisas nessa área e subsidiar estratégias de enfrentamento para essa população e políticas de saúde da mulher.

Palavras-chave: Gravidez. Inquéritos e Questionários. Análise Psicométrica. Estudos de Validação.

\section{Resumen}

Introducción: El análisis del estrés psicosocial materno durante el embarazo puede ser una herramienta de intervención importante para la salud de la madre y del bebé. Objetivo: Traducir al portugués de Brasil, adaptar culturalmente y validar la "Pregancy Experience Scale - Short-Form" para luego aplicarla a los casos de brasileñas embarazadas. Método: Se realizaron la traducción y la adaptación cultural de la escala siguiendo las recomendaciones de la guía propuesta por Beaton y colaboradores. Los datos fueron recogidos entre enero y septiembre de 2016, en hospitales, unidades básicas de salud y comunidad. En total, 206 embarazadas con edad media de 25,01 \pm 6,44 años y edad gestacional de 25,5 \pm 8,72 semanas de embarazo llenaron el formulario conforme la escala para el análisis psicométrico y validación. Resultados: La investigación desarrolló un modelo de escala bidimensional con dos factores: Experiencias positivas y Experiencias negativas. La confiabilidad se estableció mediante la prueba de Alpha de Cronbach $(\alpha>0,70)$. Tanto el valor del factor "experiencias positivas" como el de "experiencias negativas" fueron adecuados, con $\alpha=0,77$ y $\alpha=0,80$, respectivamente. Esto evidencia la confiabilidad de la escala. Se estableció la validez convergente y competidora del instrumento. Conclusión: El resultado del estudio psicométrico de la escala indica que la "Pregnancy Experience Scale" es útil para evaluar la experiencia de mujeres embarazadas, especialmente el nivel de estrés psicosocial, lo que contribuye a ampliar la investigación en el área y a desarrollar políticas estratégicas para afrontar los problemas de salud de las mujeres.

Palabras clave: Embarazo. Encuestas y Cuestionarios. Análisis Psicométrico. Estudios de Validación. 


\section{Introduction}

Pregnancy is a complex body experience lived by the women, resulting in changes and involving the reorganization of biopsychosocial and cognitive levels. It transforms the woman's relationship with her body and the environment in which she lives. It is an important developmental transition of life [1].

Anxiety during pregnancy is one of the normal adaptations most women face, especially in the first trimester, due to biopsychosocial adjustments [2, 3]. This anxiety tends to increase, at the expense of constant changes throughout the pregnancy and instability with the body image, alongside external factors, such as stress at work, and financial, social or relationship difficulties [2]. The positive influence of good sleep quality on the reduction of physical discomforts and consequently improvement of the daily life activities of pregnant women is also highlighted [4].

Physiological adaptations are precursors of reactions such as emotional and relationship instability in various dimensions of the woman's life [5]. Negative attitudes and restrictive behaviors towards weight gain could be associated with multiple psychosocial risk factors for the development of self-image during pregnancy. It is believed that women who experience positive attitudes in pregnancy are more likely to accept weight gain and bodily adaptations [6].

Studies about the body image of pregnant women focus on possible associations between the rapid physical changes and the dissatisfaction trigger with their bodies [7-10]. Body dissatisfaction, referred as a negative assessment of their body, is part of the attitudinal component of body image $[11,12]$. Dissatisfaction with their bodies, in pregnant women, may be associated with inadequate and restrictive diets [13-15] and to prenatal and postnatal depression $[9,16]$, with negative implications for the health and welfare of mother and child [17].

Remote scientific evidence points that the mother's emotional state can influence the development of the fetus. This fact affected a study carried in 1950, which examined the effects of psychosocial stress during the prenatal period of pregnant women. Currently, there is an increasing number of population-based studies on pregnant women supporting the hypothesis that women who experience high levels of psychosocial stress are susceptible to premature delivery [18].

A study [1] assessed the gestational experience, the relationship with the pregnant body and the perceived social support, identifying that the reports of pregnant women facing the pregnancy diagnosis brought higher indicators for the perception of "personal changes", lower values for "experiencing the pregnant body" and poor formulation of "maternal identity". The perception of social support showed that as greater the protection, the greater the experience of living with the pregnant body, and a more significant relationship with the mother which shows the importance of affective bonds in social support [19].

Scales that measure emotional lability during gestation are important parameters to guide the practice of healthy actions, since psychological distress, centered on stress and anxiety, can interfere with the favorable results in this period. However, adapted to accord with the cultural reality of the pregnant women, these scales better identify the perception of the feelings in this phase $[3,6]$.

Assessing the positive and negative aspects of this experience can be an important intervention tool for the health of the mother-child dyad. However, despite the relevance of this theme, there are few tools available in the literature that can measure how specific experiences in pregnancy contribute to or impact the mother's psychological state. In the Brazilian scenario, there are no available instruments to assess the impact of these experiences on the mother's psychological state.

Thus, the objective of this study was to translate, adapt and validate "Pregnancy Experience Scale" Short-Form in the Portuguese language for Brazilian pregnant women.

\section{Methods}

This is a methodological study of instrument validation, approved by the Research Ethics Committee of the Universidade do Sagrado Coração - Bauru/ SP (no. 412340/2014). The author of the original version of Pregnancy Experience Scale - Short-Form authorized the translation, cultural adaptation, and validation of the instrument for Brazilian Portuguese.

\section{Participants}

In total, 206 pregnant women participated in this study, recruited by sampling technique by trial [20] in Hospitals, Basic Health Units, and community. The inclusion criteria were that the chosen women: 1 . were 18 years old or older; 2 . were able to read and write in Portuguese Language to have the ability 
to complete the questionnaires; 3 . had a singleton pregnancy with a gestational age $\geq 13$ week. The mean age of pregnant women was $25.01(\mathrm{SD}=6.44)$ years, and gestational age of $25.5(\mathrm{SD}=8.72$ ) weeks. A signed informed consent was obtained from all the participants.

The socio-demographic profile of participants, represented by marital status, schooling and occupation, collected by the characterization questionnaire identified higher percentages of women with stable relationship (69\%), white (47.08\%), with elementary school (44.17\%), and those that do not work (55.33\%).

The sample size was calculated according to the recommendations of Malhotra [21], which determines the number between 5 and 10 women for each existing item in the instrument, in scale validation studies.

\section{Material}

Pregnancy Experience Scale - Short-Form PES [6] was developed based on the long version, to assess the daily exposure of the mother to specific positive and negative pregnancy aspects, with the intention of being administered in less time. The Brief Version of PES consists of 10 items that assess the troubles and difficulties related to pregnancy, called negative aspects, and 10 items that assess the positive aspects of pregnancy, both originated at the original version of the scale. To validate the instrument, the author administered the PES-Brief Version on 112 women with low pregnancy risk, single pregnancy, and over 24 weeks of pregnancy. The scale score is obtained based on the frequencies and intensities of negative and positive aspects values, as well as measures made by the relationship between them. The Brief Version scale presents adequate internal reliability and construct validity, and captures the maternal perception of positive and negative aspects generated by pregnancy.

The Demographic Questionnaire was applied as follows: age, marital status, ethnicity, education level, income distribution, and physical activity. Besides the described variables, we studied three questions arranged in similar scales of 01 to 10 points. The first question assesses how competent the woman feels when performing everyday tasks; the second one assesses the satisfaction with body appearance; and the third assesses the self-esteem.

\section{Procedures}

Translation and cultural adaptation of the scale

The translation and cultural adaptation of the PES - Short-Form was made according to the guidelines suggested in the Guide of the Institute for Work and Health [22], and consists of five stages: translation, VERSION synthesis, back-translation, version proposed by the expert committee and pretest.

In the first stage (translating the scale to Brazil), two fluent English speakers, Brazilian native translators worked independently. One of them had previous knowledge about the investigated construct.

The second stage consisted of a synthesis of both translations, carried out by a synthesis judge, native Portuguese and fluent English speaker, with knowledge on the investigated construct. The synthesis was developed by consensus between the translators and the judge, resulting in a single Brazilian Portuguese version.

In the third stage, the Brazilian Portuguese version (synthesis version) was retro-translated by two native English speakers, who also speak fluent Portuguese, with no previous knowledge in the field of study. They worked independently, translating the Brazilian Portuguese version to English once more. To ensure the reliability of this translation, the native English translators had no access to the original version of the original scale. Two retro-translation versions were generated.

In the fourth stage, all produced materials in earlier stages (translations, synthesis versions, retrotranslations, and the original version) were submitted to analysis by an expert committee comprised of the four translators (English and Portuguese speaking natives), one methodologist, one linguist, one professional in the area of women's health, one statistician and one pregnant woman, representing the target population. The committee assessed the equivalence of the original version and the translated version in four areas: semantic equivalence (ensuring the maintenance of meanings and grammar correction), idiomatic equivalence (equivalent expressions for the colloquialism or idiomatic expressions), experimental equivalence (ensuring the cultural relevance of tasks and examples to be used in the test) and the conceptual equivalence (ensuring the conceptual meaning for the Brazilian population). Finally, the expert committee prepared a final version that was submitted to the pretest (fifth stage), which followed the recommendations of Beaton etal. [22]. The instrument was applied to an independent sample of 30 pregnant women. There was no doubt to understand 
the instrument, given that $90 \%$ of the sample answered to the scale with no difficulties and, thus, this version was used in data collection $[21,23]$.

\section{Psychometric Study of the Scale}

The scale and sociodemographic questionnaire were applied to 206 pregnant women, who were recruited at hospitals and basic health units; they all accepted to participate and signed the consent form.

\section{Data Analysis}

The characterization of the sample and the response tendencies for the scale were performed through Descriptive Statistics with calculations of the mean, median, and standard deviation. Cronbach's alpha test verified the internal scale reliability. To assess the psychometric properties of the translated instrument were used multivariate statistical tests such as SPSS ${ }^{\circledR} 12.0$ and LISREL ${ }^{\circledR} 8.51$ software.

To validate the instrument, the Confirmatory Factor Analysis was used. The models were validated by performing successive adjustments aimed at greater adaptation of the construct. To establish the criteria for analysis of the models, were followed the recommendations of Hair Jr et al. [20], which seeks to verify the strength of the relationships between the variables that determine the factors. The models were presented by graph, following the pattern used in the literature for confirmatory factor analysis [24].
The adjustments made in the model were based on the measurements that indicate the degree of adequacy: weighted chi-square $\left(\mathrm{x}^{2} /\right.$ degrees of freedom), value $\geq 5$; Goodness-of-Fit Index (GFI) value $\leq$ 0.9; Adjusted Goodness-of-Fit Index (AGFI) value $\leq$ 0.9; Root Mean Square Error of Approximation (RMSEA) value $>0.08$; Normed Fit Index (NFI), values $\leq$ 0.9; Non-normed Fit Index (NNFI) value $\leq$ 0.9; Comparative.

The measures of degree of adequacy will be the parameters to verify unidimensionality reliability and validity of construct $[20,25]$. The adequacy of the measurement model was assessed by the analysis of the following items: factorial loadings $(\lambda \geq 0.50$ - acceptable; $\lambda \geq 0.70$ - ideal), average variance extracted (AVE $\geq 0.50$ ), Cronbach's alpha test $(\alpha \geq 0.70)$ [26] and Composite reliability $(\mathrm{CR} \geq 0.70)[20]$.

\section{Results}

In the psychometric study from PES-Brief, we started the analysis with the information obtained on median, mean, and standard deviation of answers given to each one of the 20 items of the instrument. Since there is no positive and negative factor to aggregate the respective positive or negative items, the scores were not inverted to preserve the possibility for the researcher to obtain the ratio of positive experiences [6] (Table 1).

Table 1 - Frequency, median, mean and standard deviation of answers for the PES-Brief

\begin{tabular}{|c|c|c|c|c|c|c|c|}
\hline \multirow{2}{*}{ Statements } & \multicolumn{4}{|c|}{ Answers \%* } & \multicolumn{3}{|c|}{ Descriptive statistics } \\
\hline & 0 & 1 & 2 & 3 & Median & Mean & SD \\
\hline P1. How much the baby is moving. & 4.9 & 8.7 & 24.3 & 62.1 & 3 & 2.43 & 0.84 \\
\hline P2. Discussions with spouse about baby names. & 7.9 & 9.7 & 28.6 & 53.9 & 3 & 2.28 & 0.93 \\
\hline P3. Comments from others about your pregnancy/appearance. & 5.3 & 22.8 & 36.4 & 35.4 & 2 & 2.01 & 0.89 \\
\hline P4. Making or thinking about nursery arrangements. & 4.9 & 15 & 28.6 & 51.1 & 3 & 2.26 & 0.88 \\
\hline P5. Feelings about being pregnant at this time. & 1 & 9.7 & 24.8 & 64.6 & 3 & 2.52 & 0.71 \\
\hline P6. Visits to obstetrician/midwife & 1.5 & 18.9 & 32 & 47.6 & 2 & 2.25 & 0.81 \\
\hline P7. Spiritual feelings about being pregnant. & 2.4 & 14.1 & 30.1 & 53.4 & 3 & 2.34 & 0.81 \\
\hline P8. Courtesy/assistance from others because you are pregnant. & 2.4 & 17 & 31.1 & 49.5 & 2 & 2.27 & 0.83 \\
\hline P9. Thinking about the baby`s appearance. & 1 & 4.9 & 12.6 & 81.6 & 3 & 2.74 & 0.59 \\
\hline P10. Discussions with spouse about pregnancy/childbirth issues. & 9.2 & 5.3 & 16 & 69.4 & 3 & 2.45 & 0.95 \\
\hline N1. Getting enough sleep. & 22.8 & 34 & 27.7 & 15.5 & 1 & 1.35 & 1 \\
\hline N2. Physical intimacy. & 27.2 & 39.8 & 25.2 & 7.8 & 1 & 1.13 & 0.90 \\
\hline N3. Normal discomforts of pregnancy (heartburn, incontinence). & 15 & 24.8 & 23.8 & 36.4 & 2 & 1.81 & 1.08 \\
\hline N4. Your weight. & 25.2 & 33.5 & 20.4 & 20.9 & 1 & 1.36 & 1.07 \\
\hline N5. Body changes due to pregnancy. & 24.3 & 35.9 & 20.9 & 18.9 & 1 & 1.34 & 1.04 \\
\hline N6. Thoughts about whether the baby is normal. & 24.3 & 18 & 18.4 & 39.3 & 2 & 1.72 & 1.21 \\
\hline N7. Thinking about your labor and delivery. & 15 & 17.5 & 21.5 & 45.6 & 1 & 1.98 & 1.04 \\
\hline N8. Ability to do physical tasks/chores. & 22.6 & 30.6 & 27.2 & 19.4 & 1 & 1.43 & 1.04 \\
\hline N9. Concerns about physical symptoms (pain, spotting, etc.). & 23.8 & 24.8 & 18 & 33.5 & 2 & 1.61 & 1.17 \\
\hline N10. Clothes/shoes don't fit. & 20.4 & 27.2 & 26.7 & 25.7 & 2 & 1.57 & 1.08 \\
\hline
\end{tabular}

Note: *Answers: 0: not at all; 1: somewhat; 2: quite a bit; 3: a great deal. SD: standard deviation. Source: SPSS 15. 
In Table 1, we can note the balance between positive and negative experiences in pregnancy that are reported by pregnant women.

\section{General adjustment of the model}

We initially submitted the original, onedimensional model of PES-Brief, to the confirmatory factor analysis, using the LISREL ${ }^{\circledR}$ system, employing ULS as a method of initial estimation. Model 1 suffered very poor initial adjustments $(\mathrm{RMSEA}=0.153, \mathrm{GFI}=0.82, \mathrm{AGFI}=0.78, \mathrm{NFI}=0.62$, CFI $\left.=0.68, \mathrm{NNFI}=0.65, \mathrm{x}^{2} / \mathrm{gl}=5.80\right)$. We can observe that 16 of the 20 items had very low factor loadings $\left(\lambda_{i}>0.40\right)$. In the residual analysis, we verified that items P1, P2, P3, P4, P5, P6, P7, P8, P9, P10, N2, N3, N4, N5, N7, N9, and N10 produced high waste in the model, especially items $\mathrm{P} 2$ and P10 ( $\beta=7.93)$. Thus, as an attempt to fit seems to be impracticable, we tested a second model with two factors, in which the positive and the negative experiences were organized on distinct factors. It is noteworthy that this is the same factor model used in the extended version of the Pregnancy Experiences Scale [6].

The initial setting of the two-dimensional model, generated by the method of extraction ULS, presented satisfactory values (RMSEA $=0.076$, $\mathrm{GFI}=0.94, \mathrm{AGFI}=0.93, \mathrm{NFI}=0.87, \mathrm{CFI}=0.96$, NNFI $=0.96, \mathrm{x}^{2} / \mathrm{gl}=2.18$ ). The items $\mathrm{P} 1, \mathrm{P} 6, \mathrm{P} 9$, $\mathrm{N} 3, \mathrm{~N} 9$, and N10, had low factor loadings, between $\lambda_{\mathrm{i}}=0.35$ and $\lambda_{\mathrm{i}}=0.47$. The items P2 and P10; N2 and $\mathrm{P} 2$; $\mathrm{N} 4$ and $\mathrm{N} 5$; N6 and $\mathrm{N} 7$ produced waste with each other; in which the first pair generated most waste in the model ( $\beta=5.59)$. To ensure greater data adherence, we accepted the error covariance for the items P2 and P10. The elimination of items with lower factor loadings did not improve the model adjustment, so we maintained these items to preserve the content validity. After the adjustment, the bifactorial model showed very satisfactory levels (RMSEA $=0.064, \mathrm{GFI}=0.95, \mathrm{AGFI}=0.93, \mathrm{NFI}=0.90$, $\left.\mathrm{CFI}=0.98, \mathrm{NNFI}=0.98, \mathrm{x}^{2} / \mathrm{gl}=1.90\right)$. The graphic representation is shown in Figure 01.

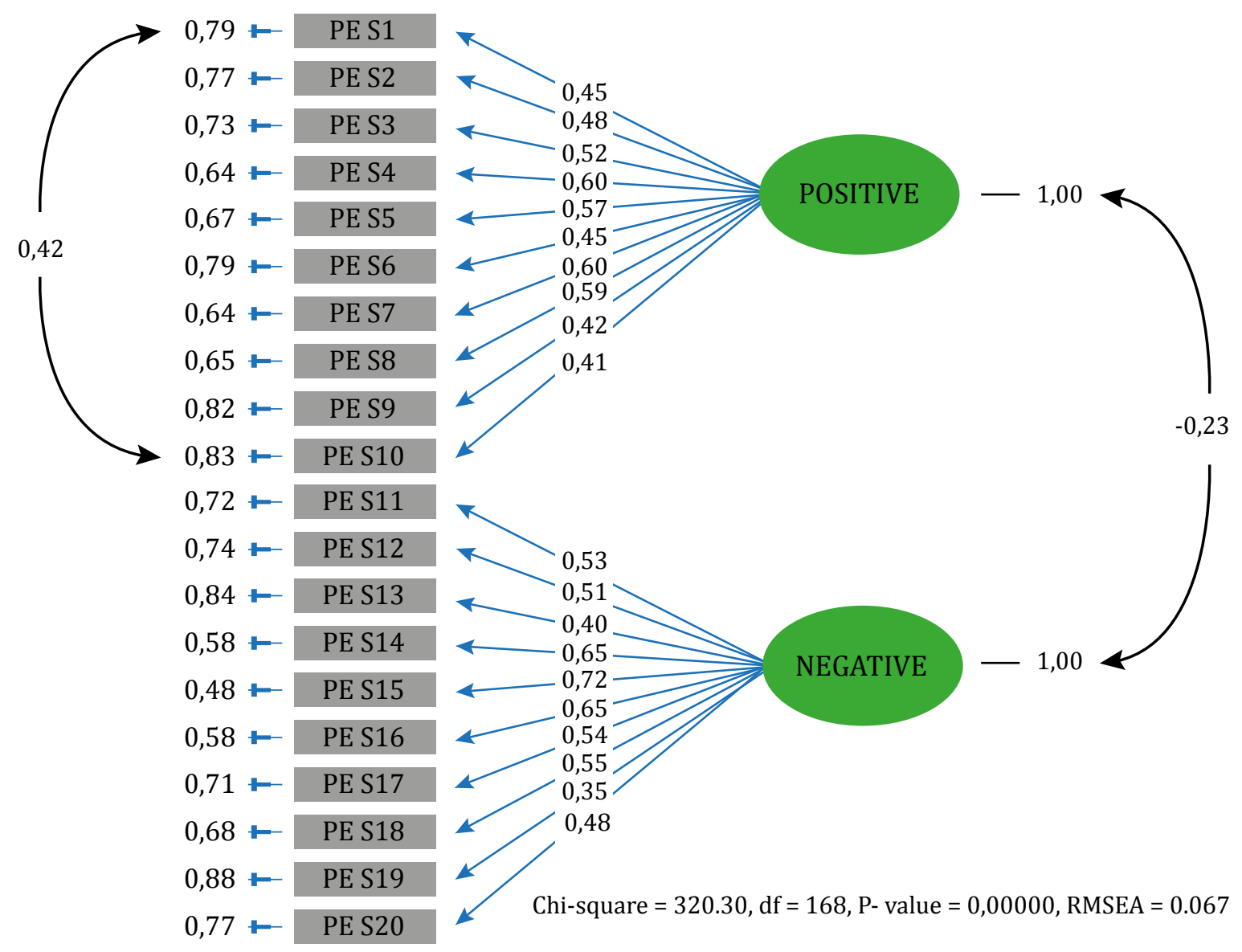

Figure 1-Graphical representation of the bifactorial model - Brazilian version of PES-Brief. Source: LISREL ${ }^{\circledR} 8.51$. 
Measurement Model Adjustment

We analyzed the internal reliability and validity of the model construct. The one-dimensionality is assessed by the value of the matrix of normalized residues construct, which should be lower than \pm 2.58 in the module, at $5 \%$ significance level. The model presented only one residue above the limit value, between the statements $\mathrm{P} 2$ and $\mathrm{N} 2(\beta=2.7), \mathrm{N} 4$ and $\mathrm{N} 5(\beta=3.49)$, and $\mathrm{N} 6$ and $\mathrm{N} 7(\beta=3.7)$. These residues do not hinder the one-dimensionality of the model, which can be confirmed by the CFI index value (0.98), from which we recognize its one-dimensionality.

To investigate the reliability of the scale, we carried out the Cronbach's Alpha test $(\alpha>0.70)$. The value of the factor "Positive experiences" was adequate: $\alpha=0.77$. The same occurred to the factor "Negative experiences", $\alpha=0.80$. These values provide internal reliability evidence for the scale.

The convergent validity was analyzed through the reliability values of the construct ( $\mathrm{CC}>0.70$ ). The values found for the factor "Positive experiences" were adequate ( $\mathrm{CC}=0.75$ ). The same happened to the factor "Negative experiences", $\mathrm{CC}=0.80$. We additionally analyzed the factor loadings and $t$-values for each item. In the model, only the factor loadings of items P9, N3, and N9 were more distant to the recommended minimum value of $\lambda_{i}=0.50$. All $t$-values were significant (considering a significance level of 5\%) and above 1.96. Despite the lower factor loadings, the $t$-values and the construct reliability point to the convergent validity, showing that the items have the ability to measure the latent variable.

For the concurrent validity, we analyzed if the score of each factor from the PES-Brief was correlated to the gross measures of satisfaction with the body, satisfaction with appearance, self-esteem, humor and perception of personal competence in carrying out daily activities. We found correlations between the analyzed variables, except for the score of factor "negative experiences" and the gross measure of humor (Table 2).

Table 2 - Correlations between the scores of the PES-Brief factors

\begin{tabular}{|c|c|c|c|c|c|c|c|}
\hline & $\begin{array}{l}\text { Positive } \\
\text { score }\end{array}$ & $\begin{array}{c}\text { Negative } \\
\text { score }\end{array}$ & Humor & $\begin{array}{l}\text { Satisfaction } \\
\text { appearance }\end{array}$ & $\begin{array}{c}\text { Satisfaction } \\
\text { body }\end{array}$ & Self-esteem & Competence \\
\hline Positive score & 1.000 & -0.10 & $0.14^{*}$ & $0.18 * \star$ & $0.28 * \star$ & $.327^{\star \star}$ & $0.22^{\star \star}$ \\
\hline Negative score & & 1.000 & -0.75 & $-0.23^{\star *}$ & $-0.26^{\star *}$ & $-.206^{\star \star}$ & $-0.18^{\star *}$ \\
\hline Humor & & & 1.000 & $0.28 * \star$ & $0.25^{\star \star}$ & $.338 \star \star$ & $0.34 * \star$ \\
\hline $\begin{array}{l}\text { Satisfaction } \\
\text { Appearance }\end{array}$ & & & & 1.000 & $0.65^{\star *}$ & $.547^{\star *}$ & $0.45^{\star \star}$ \\
\hline Satisfaction body & & & & & 1.000 & $.545^{\star \star}$ & $0.36^{\star *}$ \\
\hline Self-esteem & & & & & & 1.000 & $0.46^{\star *}$ \\
\hline Competence & & & & & & & 1.000 \\
\hline
\end{tabular}

Note: *Correlation is significant at the 0.05 level (2-tailed); ${ }^{*}$ Correlation is significant at the 0.01 level (2-tailed). Source: SPSS 15.

To determine the divergent validity, we compared the scores of the Brazilian version of PES-Brief regarding the levels of perception of financial security and the marital status. As for financial security, the test of Kruskal-Wallis showed that there are differences between the ones who declared insecure (no. $=32$ ), a little insecure (no. $=60$ ), a little secure (no. $=68$ ) and financially secure (no. $=46$ ) in the score of the factor "positive experiences", $\mathrm{x}^{2}(3.206)=8.89, \mathrm{p}=0.03$. The post hoc analysis with the Mann-Whitney test was performed using the Bonferroni correction $(\alpha=0.008)$ and identified that the differences of scores are specifically among those who feel insecure (mean $=38.58$ ) and a little secure (mean $=56.11), U=706.5 \mathrm{p}=0.005, r=0.28$.
There was no difference in the score of the factor "negative experiences", $x^{2}(3.206)=3.87, p=0.27$.

As for the marital status, no difference was identified in the score of the factor "negative experiences", $x^{2}(4.206)=6.002, p=0.19$. However, we found difference in the score of the factor "positive experiences", $x^{2}(4.206)=14.09, p=0.007$. The post hoc analysis with the Mann-Whitney test was performed by applying the Bonferroni correction $(\alpha=0.005)$. The difference is specifically among the score of single pregnant women (no. $=35$, mean $=61.91$ ) and the married pregnant women (no. $=142$, mean $=95.68)$, $U=1537, \mathrm{p}>0.0001, r=0.26$.

Table 3 represents the Brazilian Version of the Pregnancy Experience Scale, in Brief Version. 
Table 3 - Brazilian Version of the Pregnancy Experience Scale (PES-BRIEF)

\section{Pregnancy Experience Scale}

Below are 10 situations that may be considered rewarding and encouraging in your pregnancy and 10 other situations that may be considered less nice. Please, tick how each situation affects you now.

\begin{tabular}{|c|c|c|c|c|}
\hline How each situation made you feel happy, optimistic or excited? & 0 Not at all & 1 Somewhat & 2 Quite a bit & $3 \mathrm{~A}$ great deal \\
\hline 1. How much the baby is moving. & 0 & 1 & 2 & 3 \\
\hline 2. Discussions with spouse about baby names. & 0 & 1 & 2 & 3 \\
\hline 3. Comments from others about your pregnancy/appearance. & 0 & 1 & 2 & 3 \\
\hline 4. Making or thinking about nursery arrangements. & 0 & 1 & 2 & 3 \\
\hline 5. Feelings about being pregnant at this time. & 0 & 1 & 2 & 3 \\
\hline 6. Visits to obstetrician/midwife & 0 & 1 & 2 & 3 \\
\hline 7. Spiritual feelings about being pregnant. & $\mathbf{0}$ & 1 & 2 & 3 \\
\hline 8. Courtesy/assistance from others because you are pregnant. & 0 & 1 & 2 & 3 \\
\hline 9. Thinking about the baby`s appearance. & 0 & 1 & 2 & 3 \\
\hline 10. Discussions with spouse about pregnancy/childbirth issues. & 0 & 1 & 2 & 3 \\
\hline \multicolumn{5}{|l|}{ How each situation made you feel unhappy, pessimistic or upset? } \\
\hline 1. Getting enough sleep. & 0 & 1 & 2 & 3 \\
\hline 2. Physical intimacy. & 0 & 1 & 2 & 3 \\
\hline 3. Normal discomforts of pregnancy (heartburn, incontinence). & 0 & 1 & 2 & 3 \\
\hline 4. Your weight. & 0 & 1 & 2 & 3 \\
\hline 5. Body changes due to pregnancy. & $\mathbf{0}$ & 1 & 2 & 3 \\
\hline 6. Thoughts about the whether the baby is normal. & 0 & 1 & 2 & 3 \\
\hline 7. Thinking about your labor and delivery. & 0 & 1 & 2 & 3 \\
\hline 8. Ability to do physical tasks/chores. & 0 & 1 & 2 & 3 \\
\hline 9. Concerns about physical symptoms (pain, spotting, etc.). & 0 & 1 & 2 & 3 \\
\hline 10. Clothes/shoes don't fit. & 0 & 1 & 2 & 3 \\
\hline
\end{tabular}

Source: prepared by the authors.

\section{Discussion}

The objective of this study was to translate, culturally adapt and validate the PES-Brief to Brazilian pregnant women, in Brazilian Portuguese.

The process of translation and cultural adaptation of the scale followed the guidelines proposed in the Guide of the Institute for Work and Health [22], which ensured a Brazilian Portuguese version, adequate for the psychometric study.

We tested, in the psychometric study, the original one-dimensional model of PES-Brief [6] to the confirmatory factor analysis. However, this model did not reach the adequate adjustments. We then tested the factor model of the long form of the Pregnancy Experiences Scale [27], in which positive and negative experiences were organized in different factors. Thus, the model confirmed in this study was bifactorial with 20 items.
The internal reliability of the scale carried out using the Cronbach's Alpha test $(\alpha>0.70)$ showed a value of $\alpha=0.77$ for the factor "positive experiences" and $\alpha=0.80$ for the factor "Negative experiences". These reliability levels show that the scale items are interrelated and measure the latent construct.

The concurrent validity was established by analyzing if the scores of each factor from the PES-Brief correlated with the gross measures of satisfaction with the body, satisfaction with appearance, self-esteem, humor and perception of personal competence in carrying out daily activities. The results showed that positive experiences during pregnancy are associated with satisfaction with the body and appearance, as well as the perception of competence in carrying out daily activities. The changes caused to women's bodies along the pregnancy affect their daily lives, not only regarding changes in body appearance but above all in daily activities and relationships. 
The gestational experience is an organic, intense, psychosocial mix that implies changes in body image, hormones, identity, in the relationship with the partner, and even in the family environment. One of the most important aspects of positive body experiences during pregnancy is the body adaptation during this process. Adapting to bodily changes embraces the need for the mother to allow herself to experience the changes, understand and recognize how they occur in her body, and how they interfere with her life $[28,29]$.

The divergent validity was analyzed by comparing the scores of the Brazilian version of PES-Brief regarding the levels of perception of financial security and the marital status.

The Kruskal-Wallis test for financial security indicated differences between groups for the factor positive experiences, and there was no difference for the factor negative experiences. The perception of financial insecurity can negatively impact the bodily experiences during pregnancy. The socioeconomic situation directly influences living, hygiene, and dietary conditions, as well as the social environment in which the pregnant woman lives [30].

No difference was found for the score of the factor "Negative experiences", regarding the pregnant women's marital status. However, we found a difference in the score of the factor "Positive experiences". The results showed that the positive experiences are more frequent in women who have partners. A partner's support is important for effective coping with stressful events. The pregnancy evolves better when the partner shares this experience, which makes it a factor of emotional security for the pregnant woman. Marital instability is a risk factor because the mother does not have the opportunity to assume and share the responsibility for her child's life with a partner [30].

Some limitations of the study refer to crosssectional design, making it impossible to assess the causal relationship, due to the fact that the data are collected in a single moment in time, making it more difficult to establish a temporal relationship between the variables.

Other limitations include the selection technique and the sample size. The sample size was calculated using the rule of thumb that determines the number of 5 to 10 women for each item of the scale that is to be validated [21]. In this study, we used the recommended minimum sample size. Nevertheless, it was not possible to establish discriminant validity for the instrument. Still, because the sample was selected in a non-probabilistic way, it is impossible to generalize about the impact of positive and negative experiences of pregnancy on the satisfaction with the body, appearance, selfesteem, humor and competence to perform daily activities. Thus, we suggest that these differences are only present in this study.

\section{Conclusion}

The psychometric study of the scale established the construct validity, the factor structure, and the internal reliability. Thus, it was possible to verify that the instrument is reliable for use in Brazil.

The scale can be used by multiple professionals in the social and health areas. It can also be the starting point for new researches on topics of physiological adaptations in pregnancy and how these experiences interfere with the mother's psychological state and the fetus' development. We expect that the validated instrument provides subsidies to direct greater attention and care from professionals to the importance of the impact these physiological changes combined with social issues may cause in the lives of pregnant women.

\section{References}

1. Loth KA, Bauer KW, Wall M, Berge J, Neumark-Sztainer D. Body satisfaction during pregnancy. Body Image. 2011;8(3):297-300.

2. Bastard J, Tiran D. Reprint of: aromatherapy and massage for antenatal anxiety: Its effect on the fetus. Complement Ther Clin Pract. 2009;15(4):230-3.

3. Consonni EB, Calderon IM, Consonni M, Conti MH, Prevedel TTS, Rudge MVC. A multidisciplinary program of preparation for childbirth and motherhood: maternal anxiety and perinatal outcomes. Reprod Health. 2010;7:28.

4. Sousa VPS, Ribeiro SO, Aquino CMR, Viana ESR. Quality of sleep in pregnant woman with low back pain. Fisioter Mov. 2015;28(2):319-26. 
5. Hurley KM, Caulfield LE, Sacco LM, Costigan KA, Dipietro JA. Psychosocial influences in dietary patterns during pregnancy. J Am Diet Assoc. 2005;105(6):963-6.

6. DiPietro JA, Christensen AL, Costigan KA. The pregnancy experience scale-brief version. J Psychosom Obstet Gynaecol. 2008;29(4):262-7.

7. Bagheri M, Dorosty A, Sadrzadeh-Yeganeh H, Eshraghian M, Amiri E, Khamoush-Cheshm N. Pre-pregnancy body size dissatisfaction and excessive gestational weight gain. Matern Child Health J. 2013;17(4):699-707.

8. Sui Z, Turnbull D, Dodd J. Effect of body image on gestational weight gain in overweight and obese women. Women Birth. 2013;26(4):267-72.

9. Sweeney AC, Fingerhut R. Examining relationships between body dissatisfaction, maladaptive perfectionism, and postpartum depression symptoms. J Obstet Gynecol Neonatal Nurs. 2013;42(5):551-61.

10. Hodgkinson EL, Smith DM, Wittkowski A. Women's experiences of their pregnancy and postpartum body image: a systematic review and meta-synthesis. BMC Pregnancy Childbirth. 2014;14:330.

11. Cash TF, Smolak L. Body image: a handbook of science, practice, and prevention. 2nd ed. New York: The Guilford Press; 2011.

12. Borritt JMSN, Fawcett J. Body experience during pregnancy. Issues in Health Care of Women. 2009;2(3-4):1-10.

13. Dipietro JA, Millet S, Costigan KA, Gurewitsch E, Caulfield LE. Psychosocial influences on weight gain attitudes and behaviors during pregnancy. J Am Diet Assoc. 2003;103(10):1314-9.

14. Duncombe D, Wertheim EH, Skouteris H, Paxton SJ, Kelly L. How well do women adapt to changes in their body size and shape across the course of pregnancy? J Health Psychol. 2008;13(4):503-15.

15. Herring SJ, Oken E, Haines J, Rich-Edwards JW, RifasShiman SL, Kleinman ScDKP, et al. Misperceived prepregnancy body weight status predicts excessive gestational weight gain: findings from a US cohort study. BMC Pregnancy Childbirth. 2008;8:54.
16. Downs DS, DiNallo JM, Kirner TL. Determinants of pregnancy and postpartum depression: prospective influences of depressive symptoms, body image satisfaction, and exercise behavior. Ann Behav Med. 2008;36(1):54-63.

17. Fuller-Tyszkiewicz M, Skouteris H, Watson B, Hill B. Body image during pregnancy: an evaluation of the suitability of the Body Attitudes Questionnaire. BMC Pregnancy Childbirth. 2012;12:91.

18. Wadhwa PD, Entringer S, Buss C, Lu MC. The contribution of maternal stress to preterm birth: issues and considerations. Clin Perinatol. 2011;38(3):351-84.

19. Gjerdingen DK, Chaloner K. Mothers' Experience with household roles and social support during the first postpartum year. Women Heath. 1994;21(4):57-74.

20. Hair JF Jr, Anderson RE, Tatham RL, Black WB. Multivariate data analysis. 5th ed. Porto Alegre: Bookman; 2005.

21. Malhotra NK. Pesquisa de marketing: uma orientação aplicada. Porto Alegre: Bookman; 2006.

22. Beaton DE, Bombardier C, Guillemin F, Ferraz MB. Guidelines for the process of cross-cultural adaptation of self-report measures. Spine. 2000;25(24):3186-91

23. Ferreira L, Neves AN, Campana MB, Tavares MCGCF. Guia da AAOS/IWH: sugestões para adaptação transcultural de escalas. Aval Psicol. 2014;13(3):457-61.

24. Pedhazur EJ. Multiple regression in behavioral research. 3rd ed. Orlando: Harcourt Brace; 1997.

25. Garver MS, Mentzer JT. Logistics research methods: employing structural equation modeling to test for construct validity. J Bus Logist. 1999;20(1):33-57.

26. Nunnally JC. Psychometric theory. New York: McGraw Hill; 1967.

27. DiPietroJA, Ghera MM,Costigan K, Hawkins M. Measuring the ups and downs of pregnancy stress. J Psychosom Obstet Gynaecol. 2004;25(3-4):189-201. 
28. Watson B, Broadbent J, Skouteris H, Fuller-Tyszkiewicz M. A qualitative exploration of body image experiences of women progressing through pregnancy. Women Birth. 2016;29(1):72-9.

29. Roomruangwong C, Kanchanatawan B, Sirivichayakul S, Maes M. High incidence of body image dissatisfaction in pregnancy and the postnatal period: associations with depression, anxiety, body mass index and weight gain during pregnancy. Sex Reprod Healthc. 2017;13:103-9.
30. Tyrlik M, Konecny S, Kukla L. Predictors of pregnancyrelated emotions. J Clin Med Res. 2013;5(2):112-20.

Received in 06/08/2018

Recebido em 08/06/2018

Recibido en 08/06/2018

Approved in 07/01/2020

Aprovado em 07/01/2020

Aprobado en 07/01/2020 